Suvremena psihologija 19 (2016), 1, 61-70

Original scientific paper - UDK 159.963.2

DOI: $10.21465 / 2016-$ SP-191-05

\title{
THE EFFECTS OF SHIFT WORK ON CARDIAC DYNAMICS AND JOB PERCEPTION
}

\author{
Andrea Tokić \\ Department of Psychology, University of Zadar \\ Obala P. Krešimira IV 2, 23000 Zadar \\ apupic@unizd.hr
}

\begin{abstract}
Previous studies have shown negative effects of shift work on health, due to the desynchronization and resynchronization of biological rhythms. In these studies, among other parameters, indicators of cardiac dynamics were used, such as parameters of R-R interval variability, reduction in what has been considered a good predictor of health problems by some authors. The aim of this study was to determine the possible effects of shift work on the parameters of cardiac dynamics and the job perceptions of nurses of different lengths of service.

The study included 48 nurses divided in two groups ( 24 nurses in each) of equal age and length of service. One group worked a three-shift rotation system and the other (control) worked only the day shift. On the basis of length of service, the groups were divided into three comparable subgroups with eight participants: $1-10,11-20$ and 21-30 years of service. Cardiac activity (R-R intervals) was monitored continuously during the morning shift using the Data Logging System. The participants also evaluated their satisfaction with the job, the difficulty of the work, and the impact of working hours on other aspects of life.

Analysis of the results showed reduced variability in cardiac activity (DM-index) in the shift workers with up to 20 years of service, as compared with the comparative groups of day workers, which indicates a less favourable health dynamic. Differences among the oldest groups were not found, which can be attributed to spontaneous selection, where shift workers with health problems are transferred to the day shift. The shift workers were less satisfied with their job, assessing it as more difficult than the daytime workers, and showed a greater level of negative impact of working hours on other domains of life. Despite the specific and limited sample, resulting from difficulties in collecting the psychophysiological variables, the results show a satisfactory reliability and point to an adverse job perception and a cardiac dynamic less favourable for health.
\end{abstract}

Key words: cardiac dynamics, health, job satisfaction, nurses, R-R intervals, shift work 


\section{INTRODUCTION}

The parameters of heart-rate variability are considered a non-invasive marker of autonomic nervous system function (Dekker et al., 2000). More types of parameters that describe the different aspects of cardiac dynamics can be calculated from heart R-R intervals. Most common are the linear parameters, such as average value and standard deviation of R-R intervals, and parameters that reflect the functioning of the autonomic system: DM index (similar to RMSSD index) - shows the variability of successive heart beats (R-R intervals) and reflects the parasympathetic dominance in heart-rate modulation (Sztajzel, 2004); Power in the high frequency range $(H F)$ - also a marker of the parasympathetic modulation of heart rate (Sztajzel, 2004); and Power in the low frequency range (LF) - the physiological interpretation of this parameter is controversial, but most authors agree that this is a surrogate indicator of sympathetic cardiovascular modulation, through baroreflex (Berntson et al., 1997). In recent years, there has been a practice of calculating the nonlinear parameters, such as correlation dimension, as an indicator of dynamic system complexity, or the index of determinism, which indicates predictability of dynamics (Proroković, 2014). Research has shown that the linear and nonlinear parameters are good discriminators of different experimental conditions (Sarmiento et al., 2013; Šimić \& Manenica, 2012), and good predictors of health (Dekker et al., 2000). Measurements of cardiovascular dynamic in shift workers were initiated because they have a higher morbidity than day workers, and it is assumed that the genesis of disease in shift workers is related to the continuous desynchronization and resynchronization of circadian rhythms. Shift work (especially night work) interferes with normal autonomic nervous system oscillation (sympathetic dominance during the day, and parasympathetic during the night). Since the parameters of cardiac dynamics indicate the functioning of the autonomic nervous system, researchers have wanted to see whether shift work affects the cardiovascular dynamic (i.e. the functioning of the autonomic nervous system). There have been only a few studies of this topic so far, and their results have shown reduced R-R variability, and increased sympathetic and reduced parasympathetic modulation on heart activity in shift workers (Ishii et al., 2004, 2005; van Amelsvoort et al., 2001). In clinical research, changes of this type describe a less favourable dynamic, i.e. increased the risk of disease (Tsuji et al., 1996). Since shift work increases risk of disease, and the heart-rate parameters are good predictors of health, the first problem of this research was to determine whether shift work affects the heart-rate variability parameters in healthy shift workers, which can be a predictor of disease. The second problem was to compare the subjective perception of some job characteristics of shift workers with day workers, and to determine the correlation between the physiological parameters and the subjective parameters of job perception. 


\section{METHOD}

\section{Participants}

The research involved 48 nurses, employees of the General Hospitals of Zadar and Gospić, divided in two groups (24 nurses in each) of equal age and length of service. One group worked a three-shift rotation system, and the other only the morning shift. On the basis of length of service, the groups were divided into three comparable subgroups with eight participants: 1-10, 11-20 and 21-30 years of service. The sample included only healthy, premenopausal nurses. The average age in the subgroups was 29.7, 38.4 and 46.4 years.

\section{Procedure and materials}

The procedure included continuous 24-hour monitoring of cardiac activity using a portable device for recording R-R intervals (Data Logger). The monitoring of cardiac activity, for all participants, was done during a period that included two consecutive morning shifts. The recording procedure started at the end of the first morning shift and ended the next day, at the end of the second morning shift. The participants also assessed their general life/job satisfaction and job difficulty (with one 7-point item each), and influence of working hours on health, social and marital activities through the Worktime organisation effects scale (Šimunić, 2008). The scale is unidimensional, reliable (Cronbach $\alpha=.886$ ) and validated on a Croatian sample.

\section{RESULTS}

A 6-hour work period for all the participants (from 7:00 am to 1:00 pm) was analysed. Although the full shift is eight hours, due to the harmonization of the measured working period of shift and day workers, we used a shorter period for the statistical analysis. The majority of shift workers started their shift at 6:00 am and worked until 2:00 pm, and all the day workers had working hours from 7:00 am to 3:00 pm. The last working hour was ruled out of the analysis because the participants performed an experimental task during that hour: one that is not relevant to this paper.

To address the first problem, we conducted a multivariate analysis of variance with the factors type of work (shift/day), length of service in categories (1-10, 1120, and 21-30 years) and working hours for more dependent variables describing heart dynamics: DM index, power spectrum at high $(H F)$ and low $(L F)$ frequencies, and the index of determinism. 

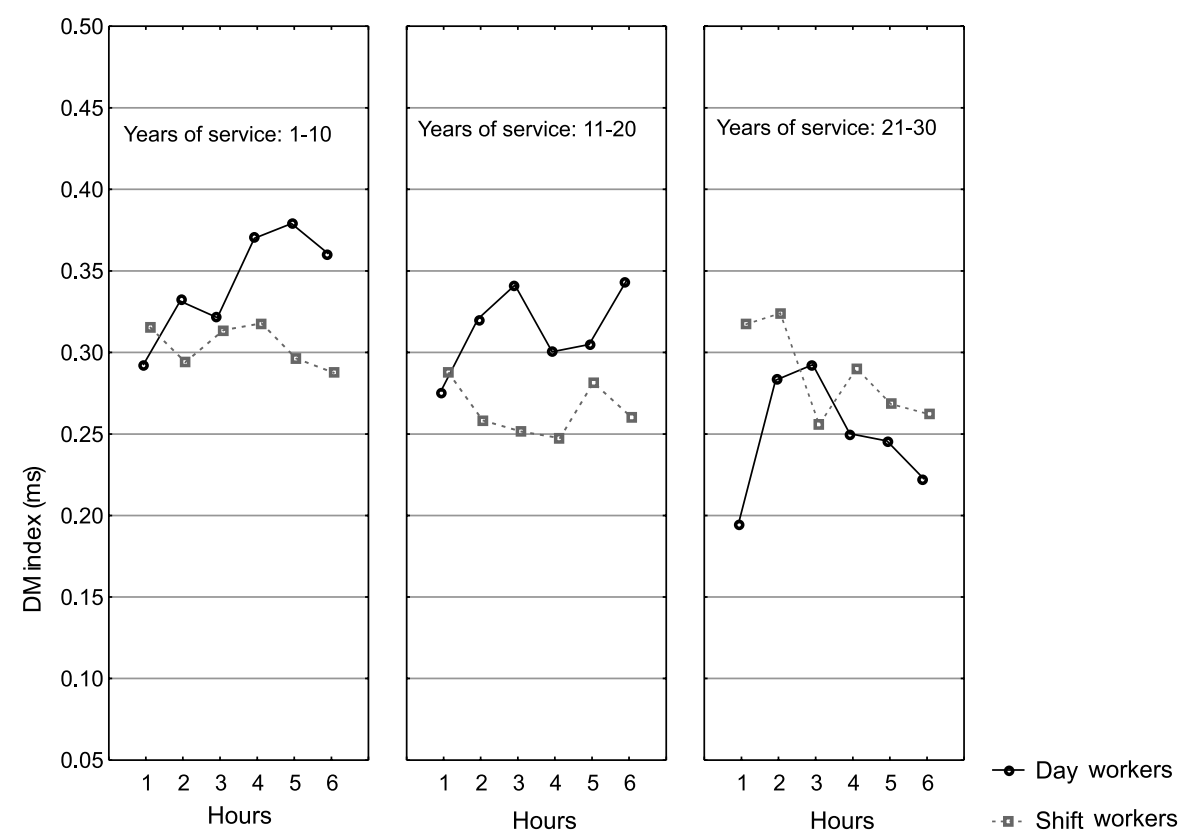

Figure 1. DM index during the working period in shift and day workers with different lengths of service

The results indicate $\left(\mathrm{F}_{(5,210)}=2.89, \mathrm{p}=.015\right)$ a significant interaction effect of work type (shift/day) and working hours on DM index. In Figure 1 we can see that the values of the DM index recorded during the first hour are the main contributors to the interaction.

By omitting the first hour from the analysis of the DM index (the first hour of shift workers is actually their second working hour, but first working hour to daily workers), the interaction was reduced, but the tendency of the DM index discrepancy between the shift and day workers became more prominent $\left(F_{(1,40)}=2.57, p=.10\right)$. A separate one-way analysis of the variance of the DM index for each category of service length between the shift and day workers showed that day workers in the first two categories of service length have higher values of DM index, the levels of risk being $10 \%\left(F_{1-10}=3.87, d f=1,14, p=.06 ; F_{11-20}=2.99, d f=1,14, p=.10\right)$. The oldest shift and day workers did not differ in this parameter $\left(F_{21-30}=0.37, d f=1,14\right.$, $p>.05$ ). Using a lower level of statistical risk seems justified because the cardiac dynamic in the working situation is influenced by numerous uncontrollable factors in addition to the shift work. The number of interfering factors is increased because the working situations are not the same for all the participants, and it is consequently logical to assume that the effects of shift work, if any appear, will not be so expressed. 
Analysis of variance of the power spectrum at low and high frequencies $\left(\mathrm{F}_{\mathrm{LF}(1,40)}=0.19, \mathrm{p}>.05 ; \mathrm{F}_{\mathrm{HF}(1,40)}=1.43, \mathrm{p}>.05\right)$ and their normalized values (LFn and $\left.\mathrm{HFn}-\mathrm{F}_{(1,40)}=0.99, \mathrm{p}>.05\right)$, showed no difference with regard to type of work.

The index of determinism, a nonlinear parameter which shows predictability of cardiac dynamics, significantly differed between the day and shift workers $\left(\mathrm{F}_{(1,40)}=8.60, \mathrm{p}=.000\right)$. ANOVA also showed significant interaction of work type and length of service $\left(\mathrm{F}_{(2,40)}=4.46, \mathrm{p}=.018\right)$ on the index of determinism. The results are shown in Figure 2.

To explain these differences, it is useful to see the correlations between the index of determinism and other parameters. For day workers, the index of determinism is positively associated with age and length of service $\left(r_{\text {age }}=.58, r_{s^{\prime} \text { length }}=.61 ; \mathrm{p}<.05\right)$, and, as expected, negatively with DM index $\left(r_{\mathrm{DM}}=-.48 ; \mathrm{p}<.05\right)$. In shift workers, there was no association of the index of determinism with age or years of service; a significant correlation was determined only with DM index $(r=-.63 ; \mathrm{p}<.05)$. On the other hand, in both groups there was a correlation between the index of determinism and the power spectrum of the high frequency range $\left(\mathrm{r}_{\text {day }}-.60 ; \mathrm{r}_{\text {shift }}=-.54\right.$; $\mathrm{p}<.05)$. These correlations, combined with the differences established in the index of determinism, probably indicate a more pronounced effect of length of service (and age, considering that seniority and age are highly positively correlated: $\mathrm{r}=.93$,
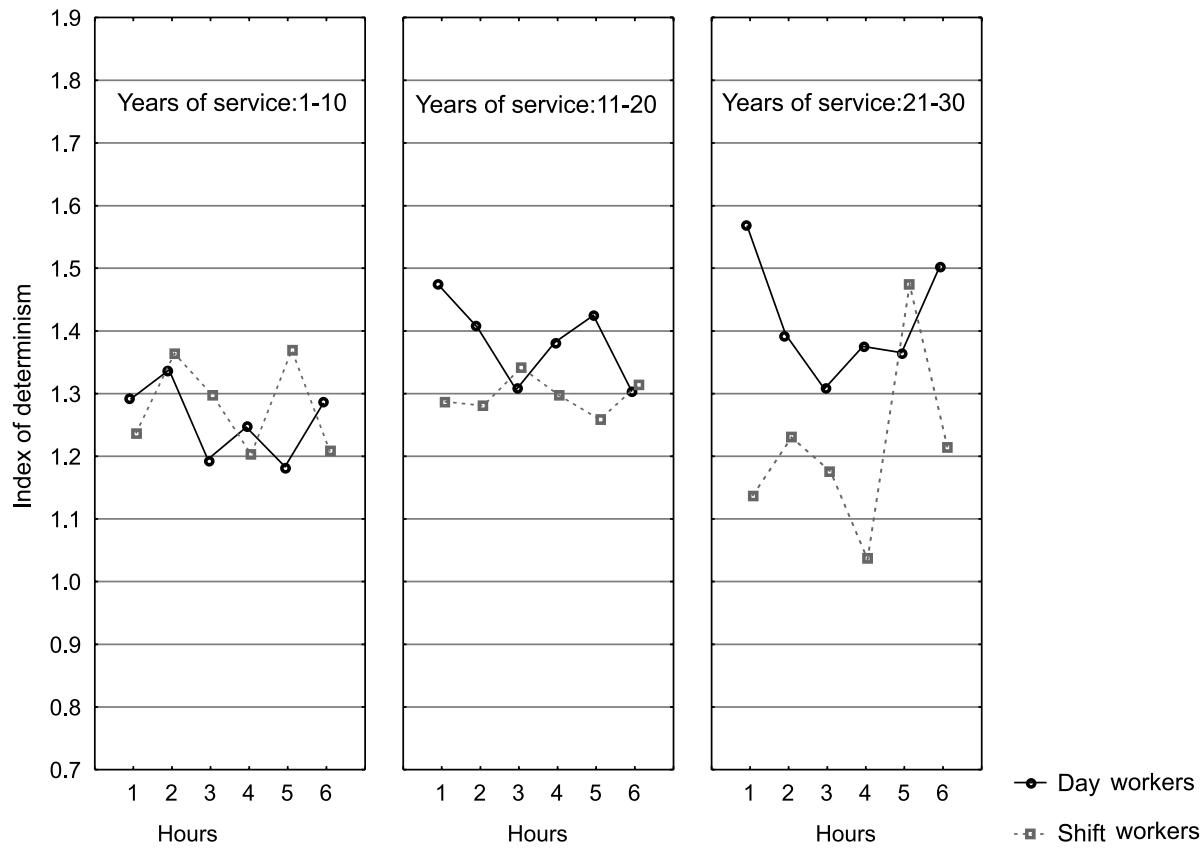

Figure 2. Index of determinism during the working period in shift and day workers with different lengths of service 

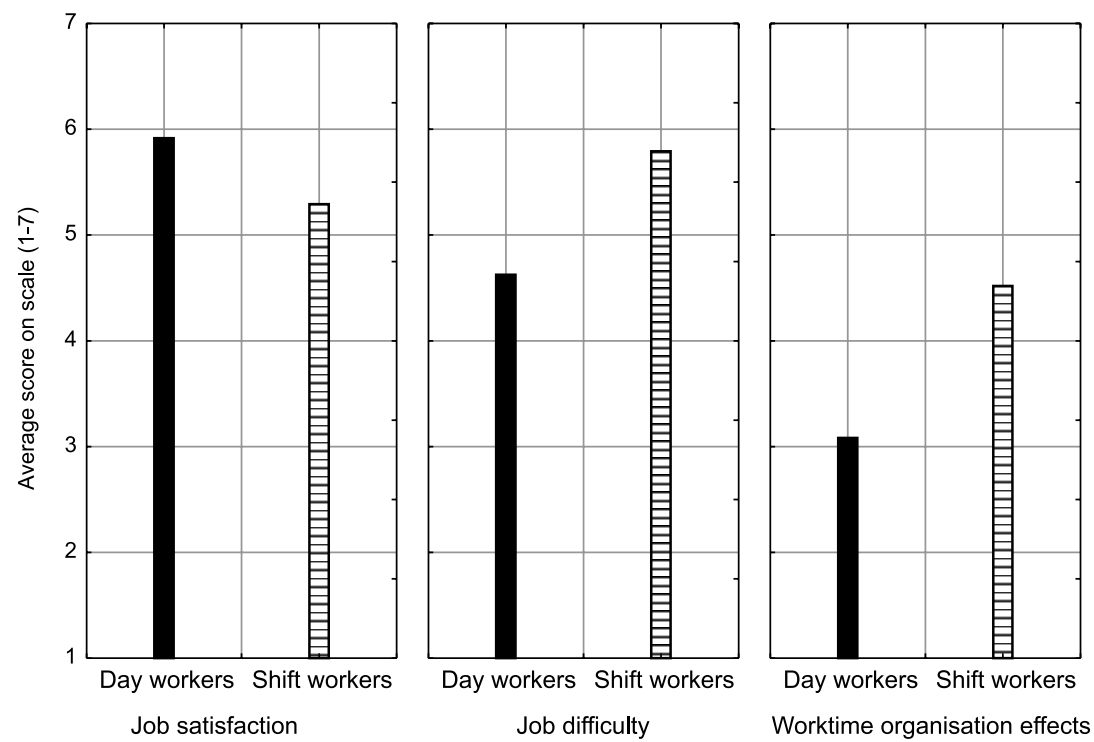

Figure 3. Average assessments of job satisfaction, job difficulty and worktime organization effects in day and shift workers.

$\mathrm{p}<.05$ ) on cardiac activity in day workers. In shift workers, shift work has a more pronounced effect on the cardiovascular dynamic in the working situation than the age/seniority effect.

This research focused primarily on the collection of physiological data, so the number of respondents was relatively small. Therefore, during the analysis of job perception (job satisfaction, job difficulty and impact of working hours on other domains of life) all shift workers were treated as one group, and all day workers as a second group, regardless of their length of service.

The analysis of variance with the factor of work type (shift/day) for the dependent variable life satisfaction showed no difference, while job satisfaction and job difficulty were significantly different between the shift and day workers. The results are shown in Figure 3.

The shift workers were less satisfied with their work $\left(\mathrm{F}_{(1,46)}=4.42, \mathrm{p}=.041\right)$ and evaluated it as more difficult than did the day workers $\left(\mathrm{F}_{(1,46)}=12.2, \mathrm{p}=.001\right)$. The analysis of the results obtained on the Worktime organisation effects scale $\left(\mathrm{F}_{(1,46)}=16.71, \mathrm{p}=.000\right)$ revealed that shift workers had a more pronounced negative impact of working hours on other aspects of life. The results are shown in Figure 3. 


\section{DISCUSSION}

The aim of this study was to determine the effects of shift work on heart dynamics in the working situation, and on job perception. Since both groups of participants were equal in all relevant characteristics and they performed the same or similar jobs, it can be assumed that all the differences in cardiac dynamics between the groups can be attributed to shift work.

There was a lower value of the DM index $(\mathrm{p}<.10)$ in shift workers who had up to 20 years' service in shifts. Since this index reflects changes in the autonomic tone that are predominantly vagally mediated (Masters et al., 2004; Sztajzel, 2004), and that there was a significant positive correlation between this index and the power spectrum of the high frequencies (HF) in day workers, it appears that the day workers had greater parasympathetic influence on cardiac activity during the working period than the shift workers. This result is in accordance with previous studies which have found decreased heart-rate variability, increased sympathetic modulation effect and decreased parasympathetic modulation effect on cardiac dynamic in shift workers (Ishii et al., 2005, 2004; van Amelsvoort et al., 2000), which indicates a type of cardiac dynamics riskier for disease. On the other hand, this result may mean that the work situation for day workers represents a less intense workload, or that the shift workers from these categories are more tired. These differences observed between the shift and the day workers may indicate a possible reversible effect of shift work, such as fatigue, an effect of previous shifts, for example, or more permanent changes in the dynamics of the cardiovascular system. The channel through which shift work has caused this change could be direct, by the interference of working hours on circadian rhythms, or indirect, by interference with the organization of family life. Considering that shift workers in general have a more demanding lifestyle that includes less sleep, more pronounced work-family conflict, and ultimately more fatigue, it is logical that the work represents a greater burden to them than to the day workers. This was reflected in their perception of the work: shift workers were less satisfied with their jobs and evaluated them as more difficult, although they were substantially similar to the jobs of the day workers.

The oldest group of day and shift workers did not differ in DM index. This result may indicate age-related changes in parasympathetic influence on the modulation of cardiac activity, and may also indicate the consequences of the so-called 'effect of the healthy shift worker' (spontaneous selection where shift workers with health problems leave shift work), which is most pronounced in the oldest of shift workers.

The results obtained in the parameter of index of determinism, a nonlinear parameter that describes the predictability of dynamics, also suggest the appearance of a 'healthy shift worker' effect. The index of determinism was higher in the oldest group of day workers than in the equivalent group of shift workers, which indicates 
an unexpected 'worse' cardiac dynamic in the day workers. For the day workers, the index of determinism increased with age/length of service (which is expected to happen with ageing), but in shift workers it decreased. In fact, the day workers' group showed age and length of service to be connected with index of determinism, DM index and HF, but there was no connection between these parameters and age or length of service in the shift workers' group. Taking this into consideration, it can be concluded that the 'healthy shift worker' effect appeared in this study. Accordingly, lower levels of index of determinism in the oldest shift workers ('better' dynamics) than in the comparative group of day workers appeared because the oldest shift workers were most exposed to self-selection. On the other hand, the lack of connection between determinism index and age in shift workers can be attributed to, beside self-selection, the dominant influence of shift work versus age on cardiac dynamic, at least in younger participants.

Individuals leaving shift work due to the accumulation of various problems can mean that the negative impact of shift work on heart dynamics in real terms is even more intense. Had the survey included those workers who were not completely healthy, as well as those who have reached menopause, then the negative effects of shift work would probably have been more pronounced.

With regard to the second research problem, it turned out that the shift workers perceived their job more negatively. They were less satisfied with their job and assessed it as more difficult. They also had a higher negative impact of working hours on other spheres of life. All of these results, despite the limitation of the small sample, indicate a negative effect of shift work on job perception. These results are in accordance with the results of previous studies (Beaujean, 2011; Jansen et al., 2003). Since a difference in the intensity of the influence of working hours on other domains of life was established, and given that previous studies have shown correlations between satisfaction with working hours and job satisfaction in shift workers (Thomas, 1991), it can be assumed that the working hours are the reason for the generally lower level of job satisfaction among shift workers.

Correlation between cardiac-dynamic parameters in the work situation and subjective assessment of the job were not significant, probably because the cardiac dynamics during the work period are influenced by many outside factors, and are not, as such, associated with more stable estimates of job characteristics.

In conclusion, from the very beginning, the shift workers had lower parasympathetic influence on cardiac dynamics in the work situation, which indicates a dynamic less favourable for health. In the oldest group, there were no such changes, probably due to the high degree of selection among shift workers. The subjective assessment of job characteristic also points to a more negative job perception among the shift workers than among the day workers. 


\section{REFERENCES}

Beaujean, C. (2011). Is work-life balance influenced by control and schedule type, and does it affect various job outcomes? (Master's Thesis, University of Tilburg: Human Resource Studies). Retrieved from: https://www.google.hr/url?sa=t\&rct=j\&q=\&esrc=s\&source= web\&cd=1\&ved=0ahUKEwj7hZfEjY7LAhXJDiwKHRBKDywQFggdMAA\&url=htt p\%3A\%2F\%2Farno.uvt.nl\%2Fshow.cgi\%3Ffid\%3D121124\&usg=AFQjCNFCt-8AaV olfpwqu4ZK1jZZkCb84g\&sig2=D3G0H9mCPbqvff-L5yS7OA\&cad=rja

Berntson, G. G., Bigger J. T., Eckberg, D. L., Grossman, P., Kaufmann, P. G., Malik, M.,... van der Molen, M. W. (1997). Heart rate variability: origins, methods, and interpretive caveats. Psychophysiology, 34(6), 623-648.

Dekker, J. M., Crow, R. S., Folsom, A. R., Hannan, P. J., Liao, D., Swennen, C. A., \& Schouten, E. G. (2000). Low heart rate variability in a 2 -minute rhythm strip predicts risk of coronary heart disease and mortality from several causes: The ARIC Study. Circulation, 102(11), 1239-1244.

Ishii, N., Dakeishi, M., Sasaki, M., Iwata, T., \& Murata, K. (2005). Cardiac autonomic imbalance and female nurses with shift work. Autonomic Neuroscience, 122(1-2), 94-99.

Ishii, N., Iwata, T., Dakeishi, M., \& Murata, K. (2004). The effects of shift work on autonomic and neuromotor functions and female nurses. Journal of Occupational Health, $46(5), 352-358$.

Jansen, N.W., Kant, I., Kristensen, T.S., \& Nijhuis, F.J. (2003). Antecedents and consequences of work-family conflict: a prospective cohort study. Journal of Occupational Medicine \& Environment, 45(5), 479-491.

Masters, J. A., Stevenson, J. S., \& Schaal, S. F. (2004). The association between moderate drinking and heart rate variability in healthy community-dwelling older women. Biological Research for Nursing, 5(3), 222-233.

Proroković, A. (2014). Deterministički kaos za nematematičare-Uvod u nelinearne analize [Deterministic chaos for nonmathematicians - Introduction to nonlinear analysis]. Jastrebarsko: Naklada Slap.

Sarmiento, S., García-Manso, J. M., Martín-González, J. M., Vaamonde, D., Calderón, J., \& Da Silva-Grigoletto, M. E. (2013). Heart rate variability during high-intensity exercise. Journal of Systems Science and Complexity, 26(1), 104-116.

Sztajzel, J. (2004). Heart rate variability: a noninvasive electrocardiographic method to measure the autonomic nervous system. Swiss Medical Weekly, 134, 514-522.

Šimic, N., \& Manenica, I. (2012). Exam experience and some reactions to exam stress. Human Physiology, 38(1), 67-72.

Šimunić, A. (2008). Konflikt radne i obiteljske uloge kod žena koje rade u smjenama. [Conflict between work and family roles in women working in shifts]. (Unpublished Master's Thesis). Department of Psychology at the University of Zadar, Zadar.

Thomas, T. L. (1991). The relationship of work schedules and circadian types to job satisfaction. (Master's Thesis, Ball State University, Indiana). Retrieved from: https://cardinalscholar.bsu.edu/handle/handle/192867

Tsuji, H., Larson, M. G., Venditti, F. J., Manders, E. S., Evans, J. C., Feldman, C. L., \& Levy, D. (1996). Impact of reduced heart rate variability on risk for cardiac events: The Framingham Heart Study. Circulation, 94(11), 2850-2855. 
van Amelsvoort, L. G., Schouten, E. G., Maan, A. C., Swennen, C. A., \& Kok, F. J. (2001). Changes in the frequency of premature complexes and heart rate variability related to shift work. Occupational and Environmental Medicine, 58(10), 678-681.

\title{
EFEKTI SMJENSKOGA RADA NA DINAMIKU SRČANE AKTIVNOSTI I PERCEPCIJU POSLA
}

\begin{abstract}
Sažetak
Dosadašnja istraživanja su pokazala negativne efekte smjenskog rada na zdravlje u čijoj se osnovi dominantno nalazi desinkronizacija i resinkronizacija bioloških ritmova. U ovakvim istraživanjima korišteni su, između ostalih, i indikatori promjena dinamike srčane aktivnosti, kao što su parametri varijabiliteta R-R intervala, čije atipično smanjenje neki autori smatraju dobrim prediktorom zdravstvenih problema. Cilj istraživanja bio je utvrditi eventualne efekte smjenskog rada na parametre srčane dinamike te percepciju posla medicinskih sestara različite dužine radnog staža.

U ispitivanju su sudjelovale dvije skupine od po 24 medicinske sestre, izjednačene po dobi i duljini radnog staža. Jedna je skupina radila u trosmjenskom sustavu rotacije smjena, a druga (kontrolna) samo u dnevnoj smjeni. Na osnovi dužine radnog staža, skupine su podijeljene u tri komparabilne podskupine s po osam sudionica, i to s: 1-10, 11-20 i 21-30 godina radnog staža. Srčana aktivnost (R-R intervali) kontinuirano je registrirana za vrijeme jutarnje radne smjene pomoću Data Logging sustava. Sudionice su također procjenjivale zadovoljstvo i težinu posla, te utjecaj radnog vremena na ostale segmente života.

Kod smjenskih radnica koje su imale do 20 godina staža utvrđen je smanjen varijabilitet srčane aktivnosti (DM-indeks) u odnosu na komparabilne grupe dnevnih radnica, što može biti indikator povećanog rizika od oboljenja. Razlike među najstarijim skupinama nisu nađene, što se može pripisati spontanoj selekciji gdje su smjenske radnice sa zdravstvenim problemima premještane u dnevnu smjenu. Smjenske radnice su bile manje zadovoljne svojim poslom, procjenjivale su ga težim nego dnevne radnice, te su iskazale veću razinu negativnog utjecaja posla na ostale domene života. Iako je zbog zahtjevnosti prikupljanja psihofizioloških varijabli uzorak u istraživanju specifičan i malen, rezultati pokazuju zadovoljavajuću pouzdanost i upućuju na nižu razinu dobrobiti smjenskih u odnosu na dnevne radnice.
\end{abstract}

Ključne riječi: medicinske sestre, R-R intervali, smjenski rad, srčana dinamika, zadovoljstvo poslom.

Prihvaćeno za tisak: 07. 09. 2016. 